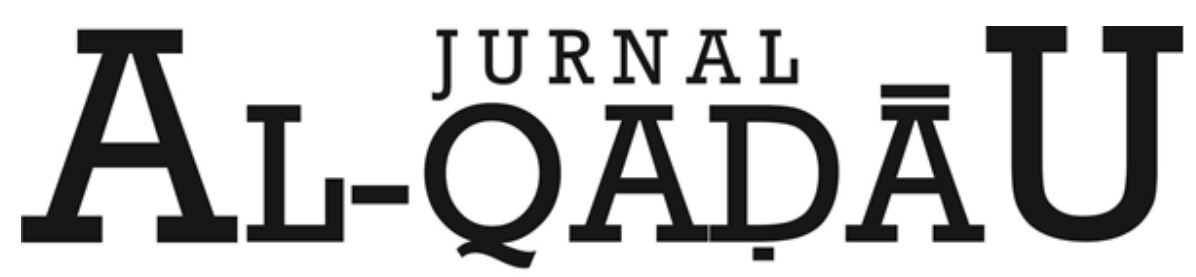

PERADILAN dan HUKUM KELUARGA ISLAM

\title{
Pembinaan Anak Tanpa Kekerasan Menurut Undang-undang No. 35 Tahun 2014 tentang Perlindungan Anak (Studi Kasus di Kelurahan Cambaya Kecamatan Ujung Tanah Kota Makassar)
}

Coaching Children Without Violence According to Law no. 35 Year 2014 on Child Protection (Case Study in Cambaya Urban Village, Ujung Tanah, Makassar City)

Muhammad Anis

Dosen Fakultas syariah dan hukum UIN Alauddin Makassar

Email : muhammadanis1966@gmail.com.

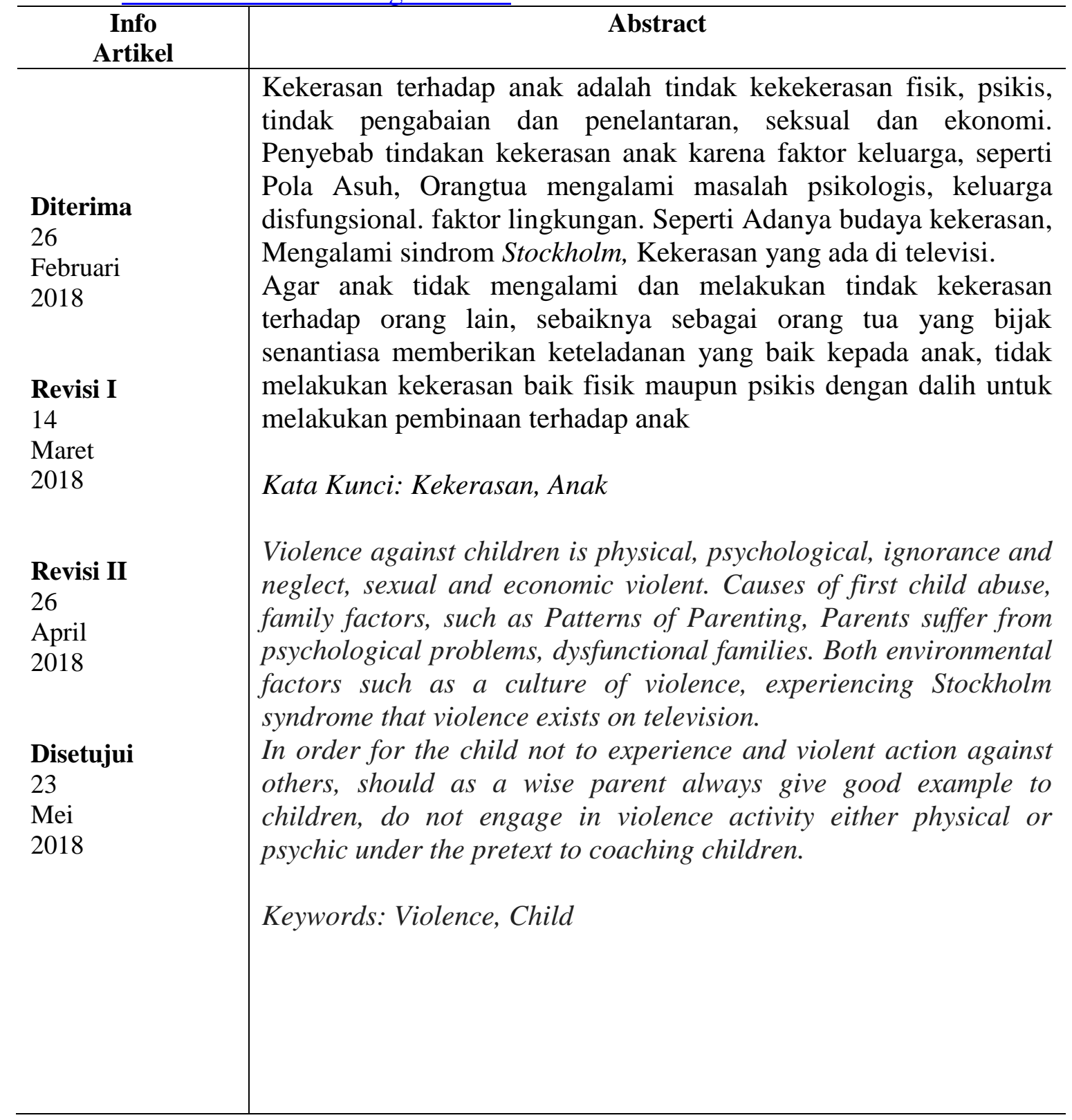




\section{A. PENDAHULUAN}

Anak merupakan karunia dari Allah swt, Seorang anak dilahirkan kedunia ini bagaikan selembar kertas putih, tanpa mengetahui seperti apa warna dunia yang akan hadir dalam kertas tersebut. Orang tua dan lingkungan sangat berperan dalam memberikan warna pada kehidupan anak. Dari orang tua dan lingkunganlah mereka belajar mana perilaku yang baik dan mana perilaku yang buruk. Pembentukan perilaku atau karakter anak dimulai sejak usia dini melalui kebiasaan sehari-hari dirumah bersama orang tua, saudara kandung, keluarga lainnya dan teman bermain juga di sekolah. Anak menurut Kitab Undang-undang Hukum Perdata Pasal 330 Kitab Undang-undang Hukum Perdata (KUHPerdata) menyatakan bahwa belum dewasa adalah mereka yang belum mencapai umur genap dua puluh satu tahun, dan tidak lebih dahulu telah kawin.

Sejak tahun 1979 pemerintah telah menetapkan sebuah peraturan untuk meletakkan anak-anak dalam sebuah lembaga proteksi yang cukup aman,yaitu dengan UU No. 4 tentang Kesejahteraan Anak yang dengan tegas merumuskan setiap anak berhak atas pemeliharaan dan perlindungan sejak dalam kandungan sampai dengan sesudah dilahirkan. Langkah pemerintah selanjutnya adalah dengan menetapkan UU Pengadilan Anak ( UU No. 3 Tahun 1997) yang diharapkan anak yang berada dalam proses hukum tetap untuk mendapatkan haknya. Terakhir, pemerintah menetapkan UU No. 35 Tahun 2014 perubahan atas UU No. 23 Tahun 2002 tentang Perlindungan Anak yang secara tegas menggariskan bahwa anak adalah penerus bangsa yang harus dijamin perlindungannya dari segala bentuk kekerasan dan diskriminasi.

Namun meskipun Undang-undang No. 35 Tahun 2014 tentang perlindungan anak telah disahkan, tetapi pelaksaan lapangan belum berjalan seperti yang diharapkan. Sedangkan, UU perlindungan anak ini diadakan dengan tujuan menjamin terpenuhinya hak-hak anak agar dapat hidup, tumbuh, berkembang, dan berpartisipasi optimal sesuai harkat dan martabat kemanusiaan, serta mendapat perlindungan dari kekerasan dan diskriminasi.

Kekerasan terhadap anak sering kali diidentikkan dengan kekerasan kasat mata, seperti kekerasan fisikal dan seksual.Padahal, kekerasan yang bersifat psikis dan sosial (stuktural) juga membawa dampak buruk permanen terhadap anak. Karenanya, istilah child abuse atau perlakuan salah terhadap anak bisa terentang mulai dari yang bersifat fisik (physical) hingga seksual (sexual abuse) ; dari yang bermatra psikis (mental abuse) hingga sosial (social abuse) yang berdimensi kekerasan stuktural.

Sebagaimana dalam Q.S Ali-Imran / 3: 159:

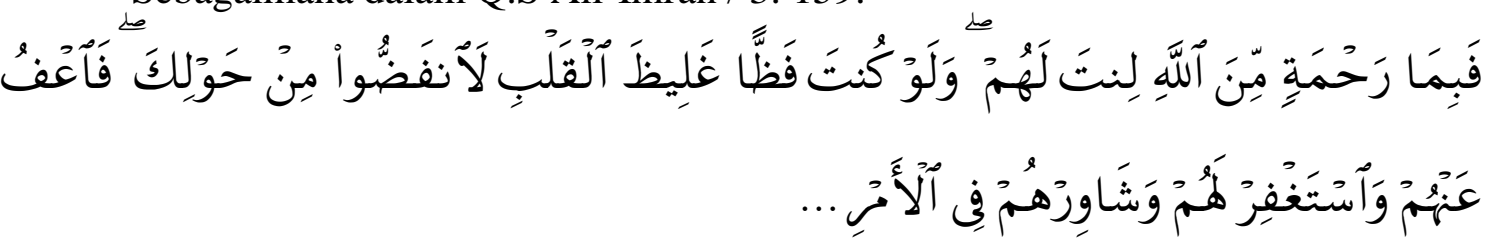

Terjemahannya:

Maka disebabkan rahmat dari Allah-lah kamu Berlaku lemah lembut terhadap mereka. Sekiranya kamu bersikap keras lagi berhati kasar, tentulah mereka menjauhkan diri dari sekelilingmu.karena itu ma'afkanlah mereka, mohonkanlah ampun bagi mereka, dan bermusyawaratlah dengan mereka dalam urusan itu. 
Dalam Surah ini Allah menyuruh manusia untuk berbuat lemah lembut. Dalam perkataan maupun perbuatan. Meskipun telah ada larangan didalam Al Qur'an namun tetap saja kekerasan pada anak sering terjadi. Sebagian mempercayai bahwa hal tersebut dapat membuat mereka berhasil dan tidak bermental lemah di masa tua. Jelas argumentum ad antiquitatem semacam ini tidak berdasar. Budaya kekerasan tidak akan menghasilkan apa-apa.

Berdasarkan Pendahuluan diatas maka penelitian ini berfokus pada pola pembinaan anak tanpa menggunakan kekerasan yang berdasar pada Al-Qur'an dan mengacu pada UU No. 35 Tahun 2014 tentang perlindungan anak terhadap kekerasan di Kota Makassar (Kelurahan Cambaya Kec Ujung Tanah).

\section{B. METODE PENELITIAN}

Jenis penelitian yang digunakan adalah penelitian lapangan (field research), lokasi penelitian di Kelurahan Camba Kecamatan Ujung Tanah Kota Makassar penelitian ini menggunakan pendekatan yuridis empiris dan yuridis normatif.

Metode Pengumpulan Data Dalam penelitian ini digunakan beberapa teknik pengumpulan data, yaitu: Observasi, dilakukan Penulis dengan cara mengamati secara langsung suatu kegiatan yang sedang dilakukan. Melalui observasi Penulis dapat memperoleh pandangan-pandangan mengenai apa yang sebenarnya dilakukan oleh orang tua terhadap pembinaan anak. Menafsirkan pesan-pesan yang ingin disampaikan. Wawancara, akan diberikan kepada narasumber sebagai salah satu sumber informasi bagi Penulis dalam menjawab rumusan masalah yang ada dengan cara mengajukan pertanyaan-pertanyaan yang erat kaitannya dengan masalah yang diangkat oleh penulis.

Instrumen Penelitian Instrumen penelitian yang dipakai untuk memperoleh datadata penelitian saat sesudah memasuki tahap pengumpulan data di lapangan seperti wawancara, observasi, Instrumen penelitian ini merujuk pada metodologi penelitian.

Teknik Pengolahan dan Analisis Data, bahwa Data yang diperoleh dan dikumpulkan dianalisa secara kuantitatif yaitu suatu cara penelitian yang yang dilakukan guna mencari kebenaran kuantitattif.

\section{PEMBAHASAN}

\section{Tinjauan Umum Mengenai Anak Pengertian Anak}

Menurut perundang-undangan yang berlaku di Indonesia, ketentuan batas kedewasaan merupakan tolak ukur pengertian anak, diantaranyaadalah sebagai berikut :

a. Anak menurut ketentuan umum Pasal 1 angka 2 Undang-undang Nomor 4 Tahun 1979 tentang Kesejahteraan Anak disebutkan bahwa anak adalah seorang yang belum mencapai umur 21 (dua puluh satu) tahun dan belum kawin. ${ }^{1}$

b. Anak menurut Undang-Undang Nomor 3 Tahun 1997 tentang Pengadilan Anak dinyatakan bahwa anak adalah orang yang dalam perkara anak nakal telah mencapai umur 18 (delapan belas) tahun dan belum pernah kawin. ${ }^{2}$

\footnotetext{
${ }^{1}$ Undang-undang Nomor 4 Tahun 1979 tentang Kesejahteraan Anak.

${ }^{2}$ Undang-Undang Nomor 3 Tahun 1997 tentang Pengadilan Anak.
} 
c. Anak menurut Undang-Undang Nomor 35 Tahun 2014 tentang Perlindungan Anak dinyatakan bahwa anak adalah seorang yang belum berusia 18 (delapan belas) tahun baik anak yang masih berada dalam kandungan. ${ }^{3}$

d. Anak menurut Kitab Undang-Undang Hukum Pidana Kitab Undang-Undang Hukum Pidana memberikan pengertian anak pada batasan belum cukup umur tampak dalam Pasal 45 yang menyatakan dalam menuntut orang yang belum cukup umur (minderjaring) karena melakukan perbuatan sebelum umur enam belas tahun. Pada Pasal 45 Kitab Undang-Undang Hukum Pidana mendefinisikan anak adalah yang orang belum dewasa atau belum berumur enam belas tahun. Oleh karena itu, apabila seseorang tersangkut dalam perkara pidana hakim boleh memerintahkan supaya tersalah dikembalikan kepada orang tuanya, walinya pemeliharaannya dengan tidak dikenakan hukuman atau memerintahkannya supaya diserahkan kepada pemerintah dengan tidak dikenakan suatu hukuman. ${ }^{4}$

e. Anak menurut Kitab Undang-undang Hukum Perdata Pasal 330 Kitab Undang-undang Hukum Perdata (KUHPerdata) menyatakan bahwa belum dewasa adalah mereka yang belum mencapai umur genap dua puluh satu tahun, dan tidak lebih dahulu telah kawin. ${ }^{5}$

Bertitik tolak dari aspek pengertian anak di atas, ternyata hukum positif Indonesia tidak mengatur unifikasi hukum pasti dan berlaku universal untuk menentukan kriteria batasan umur terhadap seorang anak. Oleh sebab itu, mengenai batas anak yang masih digolongkan sebagai anak terdapat perbedaan penentuan. Dalam hal ini, Irma Setyowati Soemitro mengambil garis batas bahwa terhadap perbedaan batasan umur yang ada di dalam hukum positif Indonesia terdapat perbedaan, maka diambil garis batas pengertian anak berlaku untuk anak yang berusia 18 (delapan belas) tahun.

\section{Tinjauan Umum Kekerasan \\ Pengertian Kekerasan}

Kekerasan berarti penganiyaan, penyiksaan, atau perlakuan salah. Kekerasan dapat diartikan sebagai perihal keras atau perbuatan seseorang atau sekelompok orang yang menyebabkan cedera atau matinya orang lain dan menyebabkan kerusakan fisik pada orang lain. ${ }^{6}$ Pada penjelasan Pasal 89 KUHP dijelaskan bahwa : ${ }^{7}$ Melakukan kekerasan artinya mempergunakan tenaga atau kekuatan jasmani secara tidak sah, misalnya memukul dengan tangan atau dengan segala macam senjata, menyepak, menendang, dan lain sebagainya. Yang disamakan dengan kekerasan menurut Pasal ini adalah membuat orang menjadi pingsan atau tidak berdaya.

\footnotetext{
${ }^{3}$ Undang-Undang Nomor 35 Tahun 2014 tentang Perlindungan Anak.

${ }^{4}$ Kitab Undang-Undang Hukum Pidana Kitab Undang-Undang Hukum Pidana.

${ }^{5}$ Kitab Undang-undang Hukum Perdata Pasal 330 Kitab Undang-undang Hukum Perdata (KUHPerdata).

${ }^{6}$ W.J.S Poerwadarminta, Kamus Umum Bahasa Indonesia (Jakarta : P.N Balai Pustaka, 1990) h.425.

${ }^{7}$ R.Soesilo, Kitab Undang-Undang Hukum Pidana Serta Komentarnya Pasal Demi Pasal (Bogor: Politea, 1991), h.84.
} 
Namun perlu diketahui bahwa dalam melakukan kekerasan bukan hanya dilakukan terhadap orang lain saja. Memberikan penjelasan mengenai kekerasan adalah sebagai berikut ${ }^{8}$

Kekerasan dapat dilakukan dalam beberapa cara, yaitu :

a. Pengerusakan terhadap barang;

b. Penganiyaan terhadap hewan atau orang; Melemparkan batu-batu kepada orang atau rumah;

c. Membuang-buang barang hingga berserakan, dan lain sebagainya.

Berdasarkan urain tersebut dapat disimpulkan bahwa objek kekerasan bukan hanya pada orang, tetapi juga pada benda atau hewan. Kata kekerasan setara dengan kata violence dalam bahasa Inggris yang diartikan sebagai suatu serangan atau invasi terhadap fisik maupun integritas mental psikologis seseorang. Sementara kata kekerasan dalam bahasa Indonesia umumnya dipahami hanya serangan fisik belaka. Dengan demikian, bila pengertian violence sama dengan kekerasan, maka kekerasan di sini merujuk pada kekerasan fisik maupun psikologis. ${ }^{9}$

Menurut para ahli kriminologi, "kekerasan" yang mengakibatkan terjadinya kerusakan adalah kekerasan yang bertentangan dengan hukum. Oleh karena itu, kekerasan merupakan kejahatan. Berdasarkan pengertian inilah sehingga kasus-kasus kekerasan terhadap perempuan dalam rumah tangga dijaring dengan pasal -pasal KUHP tentang kejahatan. Terlebih lagi jika melihat defenisi yang dikemukakan oleh Sanford Kadish dalam Encyclopedia of Criminal Justice, yaitu bahwa kekerasan adalahsemua jenis perilaku yang tidak sah. Terkadang baik berupa suatu tindakan nyata berupa maupun berupa kecaman yang mengakibatkan pembinasaan atau kerusakan hak milik.

Menurut Santoso ${ }^{10}$ kekerasan juga bisa diartikan sebagai serangan memukul (Assault and Battery) merupakan kategori hukum yang mengacu pada tindakan ilegal yang melibatkan ancaman dan aplikasi aktual kekuatan fisik kepada orang lain. Serangan dengan memukul dan pembunuhan secara resmi dipandang sebagai tindakan kolektif. Jadi, tindakan individu ini terjadi dalam konteks suatu kelompok, sebagaimana kekerasan kolektif yang mucul dari situasi kolektif yang sebelumnya didahului oleh berbagai gagasan, nilai, tujuan, dan masalah bersama dalam periode waktu yang lebih lama.

\section{Bentuk -bentuk Kekerasan}

Kejahatan kekerasan di dalam Kitab Undang -Undang Hukum Pidana (KUHP), pengaturannya tidak di satukan dalam satu bab khusus, akan tetapi terpisah-pisah dalam bab tertentu. Di dalam KUHP kejahatan kekerasan dapt digolongkan, sebagai berikut : ${ }^{11}$

a. Kejahatan terhadap nyawa orang lain Pasal 338-350 KUHP;

b. Kejahatan penganiyayaan Pasal 351-358 KUHP;

c. Kejahatan seperti pencurian, penodongan, perampokan Pasal 365 KUHP;

d. Kejahatan terhadap kesusilaan, khususnya Pasal 285 KUHP;

${ }^{8}$ R.Soesilo, Kitab Undang-Undang Hukum Pidana Serta Komentarnya Pasal Demi Pasal, h.126.

${ }^{9}$ Soejono Sukanto, Kriminologi (Pengantar Sebab-sebab kejahatan), (Bandung, Politea,1987) h.125.

${ }^{10}$ Topo Santoso, Kriminologi (Jakarta : Grafindo Persada, 2002) h. 24.

${ }^{11}$ R. Soesilo, Kitab Undang-Undang Hukum Pidana Serta Komentarnya Pasal Demi Pasal, h. $84-85$. 
e. Kejahatan yang menyebabkan kematian, atau luka kealpaan, Pasal 359 -367 KUHP

Berdasarkan penggolongannya bentuk kekerasan terbagi lagi ke dalam tiga golongan, yaitu $:^{12}$

\section{Kekerasan Fisik}

Bentuk ini yang paling mudah dikenali, kategori kekerasan jenis ini adalah melempar, menendang, memukul / menampar, mencekik, mendorong, mengigit, membenturkan, mengancam dengan benda tajam dan sebagainya. Korban kekerasan jenis ini biasanya tampak secara langsung pada fisik korban seperti luka memar, berdarah, patah tulang, pingsan dan bentuk lain yang kondisinya lebih berat.

Kekerasan nyata yang dapat dilihat, dirasakan oleh tubuh.Wujud kekerasan fisik berupa penghilangan kesehatan atau kemampuan normal tubuh, sampai pada penghilangan nyawa seseorang.

\section{Kekerasan Psikis}

Kekerasan jenis ini tidak begitu mudah dikenali, akibat yang dirasakan korban tidak memberikan bekas yang nampak jelas bagi orang lain. Dampak kekerasan ini akan berpengaruh pada situasi perasaaan yang tidak aman dan nyaman, menurunnya harga diri serta martabat korban. Wujud kongkrit kekerasan atau pelanggaran jenis ini adalah pengunaan kata-kata kasar, penyalahgunaan kepercayaan, mempermalukan orang di depan orang lain atau di depan umum, melontarkan ancaman dengan kata-kata dan sebagainya. Akibat adanya perilaku tersebut biasanya korban akan merasa rendah diri, minder, merasa tidak berharga, dan lemah dalam membuat keputusan.Kekerasan yang memiliki sasaran pada rohani atau jiwa sehingga dapat mengurangi bahkan menghilangkan kemampuan normal jiwa. Contoh : kebohongan, indoktrinasi, ancaman, dan tekanan.

\section{Kekerasan seksual}

Kekerasan yang berupa perlakuan tidak senonoh dari orang lain, kegiatan yang menjurus pada pornografi, perkataan-perkataan porno, dan melibatkan anak dalam proses prostitusi dan lain sebagainya.

Termasuk dalam kategori ini adalah segala tindakan yang muncul dalam bentuk paksaan atau mengancam untuk melakukan hubungan seksual, melakukan penyiksaan atau bertindak sadis serta meninggalkan termasuk mereka yang tergolong masih berusia anak-anak. Setelah melakukan hubungan seksualitas segala perilaku yang mengarah pada tindakan pelecehan seksual terhadap anak-anak, di dalam keluarga, maupun lingkungan sekitar tempat tinggal anak termasuk dalam kategori kekerasan ini.

\section{Kekerasan terhadap Anak}

Pengertian kekerasan terhadap anak dalam istilah sangat terkait dengan kata Abuse yaitu kata yang biasa diterjemahkan menjadi kekerasan, penganiayaan, penyiksaan, atau perlakuan salah. ${ }^{13}$ Kata ini didefinisikan sebagai "improper behavior intended to cause phisycal, psychological, or financial harm to an individual or group" (kekerasan adalah perilaku tidak layak dan mengakibatkan kerugian atau bahaya secara fisik, psikologis, atau finansial, baik yang dialami individu maupun

12 Johan Galtung, Kekuasaan dan Kekerasan (Yogyakarta : Kanisius, 1992) h. 62.

${ }^{13} \mathrm{Abu}$ Hurairah, Kekerasan terhadap Anak: Fenomena Masalah Sosial Krisis di Indonesia (Bandung : Nuansa (Anggota IKAPI), 2006), h.36. 
kelompok).Sedangkan kekerasan terhadap anak (child abuse) adalah istilah yang biasa digunakan untuk menyebut kekerasan terhadap anak.

Marzuki Umar Sa'abah mengemukakan (child abuse) adalah tindakan orang dewasa terhadap anak dengan cara yang disadari ataupun tidak yang berakibat menganggu proses tumbuh kembang anak. Sehingga dapat menimbulkan cacat fisik, mental bahkan kematian pada anak. ${ }^{14}$

\section{Bentuk- bentuk Kekerasan terhadap Anak}

Bentuk-bentuk kekerasan terhadap anak menurut Mieke Diah Anjar Yanti adalah sebagai berikut $:^{15}$

a. Kekerasan fisik adalah tindakan yang menyebabkan rasa sakit atau potensi menyebabkan sakit yang dilakukan oleh orang lain, dapat terjadi sekali atau berulang kali seperti dipukul, ditendang, ditempeleng, dijewer, dicubit, dilempar dengan benda keras, dijemur di bawah terik sinar matahari.

b. Kekerasan seksual adalah keterlibatan anak dalam kegiatan seksual yang tidak dipahaminya seperti perlakuan tidak senonoh dari orang lain, kegiatan yang menjurus pada pornografi, perkataan-perkataan porno, perbuatan cabul dan persetubuhan pada anak-anak yang dilakukan orang lain dengan tanpa tanggung jawab, tingkatan mendorong atau memaksa anak terlibat dalam kegiatan seksual yang melanggar hukum seperti dilibatkan pada kegiatan prostitusi.

c. Kekerasan psikis adalah segala sesuatu yang dapat menyebabkan terhambatnya perkembangan psikologis anak seperti kata-kata yang mengancam, menakut-nakuti, berkata-kata kasar, mengolok-olok, perlakuan diskriminatif, membatasi kegiatan sosial dan kreasi.

d. Kekerasan ekonomi (eksploitasi komersial) adalah penggunaan anak untuk bekerja dan kegiatan lainnya demi kebutuhan orang tuanya atau orang lain seperti menyuruh anak bekerja secara berlebihan, menjerumuskan anak kepada dunia prostitusi untuk kepentingan ekonomi.

e. Tindak pengabaian dan penelantaran adalah ketidakpedulian orang tua, orang yang bertanggung jawab atas anak pada kebutuhan mereka seperti pengabaian pada kesehatan anak, pengabaian dan penelantaran pada pendidikan anak, pengabaian pada pengembangan emosi, penelantaran pada pemenuhan gizi, pengabaian dan penelantaran pada penyediaan perumahan, pengabaian pada kondisi keamanan dan kenyamanan.

\section{Peranan Hukum Perlindungan Anak Terhadap Kekerasan Anak Kelurahan Cambaya}

Peranan Hukum Perlindungan Anak Terhadap Kekerasan Anak, penelitian ini berlokasi di Cambaya kecamatan Ujung Tanah Kota Makassar.

Secara spesifik disebutkan dalam Pasal 54 Undang-Undang No. 35/2014 tentang Perubahan Atas Undang-Undang No. 23/2002 tentang Perlindungan Anak, aparat atau

\footnotetext{
${ }^{14}$ Marzuki Umar Sa'abah, Perilaku Seks Menyimpang dan Seksualitas Kontemporer Umat Islam (Yogyakarta : UII Pres, 2006), h. 91.

${ }^{15}$ Mieke Diah Anjar Yanit, dkk., Model Sistem Monitoring dan Pelaporan Anak dan Perempuan Korban Kekerasan (Propinsi Jateng : Bapenas 2006), h. 9-11.
} 
masyarakat untuk memberikan perlindungan terhadap anak terhadap tindak kekerasan fisik, psikis, seksual dan kejahatan lainnya yang dibiarkan oleh Aparat Penegak Hukum dan/atau pihak lain. Bagi mereka yang menempatkan, membiarkan, melakukan, menyuruh melakukan atau turut serta melakukan kekerasan terhadap anak, mengakibatkan luka berat atau kematian juga tidak luput dari ancaman pidana penjara dan/atau denda, namun kenyataan yang terjadi di Kelurahan Cambaya Kecamatan Ujung Tanah Kota Makassar, sering terjadi tindak kekerasan terhadap anak baik kekerasan fisik maupun kekerasan fsikis sering terjadi, akan tetapi perlakuan kekerasan tersebut yang dilakukan oleh baik orang tua, maupun masyarakat itu sendiri, tidak tersentuh oleh hukum, misalnya seorang ayah yang telah melakukan kekerasan fisik terhadap anaknya (kami tidak sebutkan namanya), yang mengakibatkan luka memar pada tubuh anak tersebut dan ini terjadi secara berulang ulang dan tidak ada yang memeprsoalkan, namun mereka menganggap bahwa itu adalah merupakan model pembinaan yang dilakukan untuk menyadarkan anak agar tidak nakal, ada juga seorang ibu yang dengan dalih melakukan pembinaan kepada sang anak dengan cara menyakiti jasmaninya, mencubit, menjambak rambutnya, dan lain-lain, dan juga menyakiti psikisnya dengan cara mengeluarkan kata-kata yang tidak pantas didengar oleh anak tersebut yang seharusnya tidak boleh seperti itu.

\section{Faktor-faktor yang menyebabkan kekerasan terhadap anak.}

Faktor-faktor Penyebab Kekerasan terhadap anak dapat terjadi karena beberapa faktor, yaitu:

\section{Dari Orang tua}

Ada beberapa faktor yang menyebabkan Orang tua melakukan kekerasan terhadap anaknya, yaitu:

a. Kurangnya pengetahuan bahwa kekerasan baik fisik maupun psikis tidak efektif untuk memotivasi anak atau merubah perilaku, malah beresiko menimbulkan trauma psikologis dan melukai harga diri sorang anak.

b. Adanya masalah psikologis yang menyebabkan hambatan dalam mengelola emosi hingga orang ybs menjadi lebih sensitif dan reaktif.

c. Adanya tekanan kerja : sebagai buruh harian lepas yang hari ini bekerja untuk kebutuhan sehari-hari tidak seimbang dengan kebutuhan hidup yang harus ditanggung.

\section{Orang tua mengalami masalah psikologis}

Jika orang tua mengalami masalah psikologis yang berlarut-larut, bisa mempengaruhi pola hubungan dengan anak. Misalnya, orang tua yang stress berkepanjangan, jadi sensitif, kurang sabar dan mudah marah pada anak, atau melampiaskan kekesalan pada anak. Lama kelamaan kondisi ini mempengaruhi kehidupan pribadi anak. Ia bisa kehilangan semangat, daya konsentrasi, jadi sensitif, reaktif, cepat marah, dsb.

\section{Keluarga disfungsional}

Keluarga yang mengalami disfungsi punya dampak signifikan terhadap sang anak. Keluarga yang salah satu anggotanya sering memukul, atau menyiksa fisik atau emosi, intimidasi anggota keluarga lain; atau keluarga yang sering konflik terbuka tanpa ada resolusi, atau masalah berkepanjangan yang dialami oleh keluarga hingga menyita energy psikis dan fisik, hingga mempengaruhi interaksi sosial, situasi demikian sangat mempengaruhi kondisi emosi anak dan lebih jauh mempengaruhi perkembangan kepribadiannya. 


\section{Dari Lingkungan}

Tak dapat dipungkiri bahwa kekerasan yang terjadi selama ini juga terjadi karena adanya faktor lingkungan, yaitu:

a. Adanya budaya kekerasan : seseorang melakukan kekerasan karena dirinya berada dalam suatu kelompok yang sangat toleran terhadap tindakan kekerasan. Anak yang tumbuh dalam lingkungan tersebut memandang kekerasan hal yang biasa / wajar.

b. Mengalami sindrom Stockholm : Sindrom Stockholm merupakan suatu kondisi psikologis dimana antara pihak korban dengan pihak aggressor terbangun hubungan yang positif dan later on korban membantu aggressor mewujudkan keinginan mereka. Contoh, kekerasan yang terjadi ketika mahasiswa senior melakukan kekerasan pada mahasiswa baru pada masa orientasi bersama terjadi karena mahasiswa senior meniru sikap seniornya dulu dan dimasa lalunya juga pernah mengalami kekerasan pada masa orientasi

c. Tayangan televisi yang banyak berbau kekerasan : Jika seseorang terlalu sering menonton tayangan kekerasan maka akan mengakibatkan dirinya terdorong untuk mengimitasi perilaku kekerasan yang ada di televisi. Sebab, dalam tayangan tersebut menampilkan kekerasan yang diasosiasikan dengan kesuksesan, kekuatan dan kejayaan seseorang. Akibatnya, dalam pola berpikir muncul premis bahwa jika ingin kuat dan ditakuti, pakai jalan kekerasan.

\section{PENUTUP}

\section{Kesimpulan} berikut:

Uraian yang telah dikemukakan di atas, dapat diambil kesimpulan sebagai

1. Peranan hukum Perlindungan Anak Sesuai pasal 55 Undang-undang Nomor 35 Tahun 2014 sudah diterapkan namun kekerasan terhadap anak masih terjadi karena ketidak tahuan tentang aturan yang ada, selaku orang tua yang seharusnya memberikan perlindungan terhadap anak justru menjadi pelaku kekerasan terhadap anak dengan tetap memberikan hukuman kepada anak yang berulangkali melakukan kekerasan dengan alasan untuk memberikan efek jera pada anak.

2. Kekerasan dapat terjadi karena adanya faktor dari Keluarga

Pola Asuh.

Orangtua mengalami masalah psikologis.

Keluarga disfungsional

3. Kekerasan dapat terjadi karena adanya faktor lingkungan, diantaranya

Adanya budaya kekerasan

Mengalami sindrom Stockholm

Kekerasan yang ada di televisi

\section{Implikasi}

1. Anak sangat membutuhkan kasih sayang, membutuhkan perhatian, anak memiliki rasa, sebagai orang tua yang baik tidak melakukan kekerasan terhadap anaknya, cara yang paling tepat untuk menunjukkan kasih sayang adalah dengan bersikap lemah lembut dan bertindak cepat dan tepat dalam menyelesaikan masalah yang dihadapi oleh anak. 
2. Dampak yang timbul akibat dari kekerasan yang dialami oleh anak, seorang anak akan menganggap bahwa, memukul, mencubit, menjambak rambut, atau menyakiti orang lain adalah hal yang boleh dilakukan ketika ada yang membuat anak tersebut marah.

3. Agar anak tidak melakukan kekerasan terhadap orang lain, sebaiknya sebagai orang tua yang bijak senantiasa memberikan keteladanan yang baik kepada anak, tidak melakukan kekerasan baik fisik maupun fsikis dengan dalih untuk melakukan pembinaan terhadap anak. Meskipun demikian jika anak melakukan sebuah kekeliruan sebaiknya anak tidak hanya mendapatkan perlindungan tapi juga diberikan sanksi yang diatur dalam Undang-undang.

\section{DAFTAR PUSTAKA}

Abu Hurairah, Kekerasan terhadap Anak: Fenomena Masalah Sosial Krisis di Indonesia. Bandung : Nuansa (Anggota IKAPI), 2006.

Marzuki Umar Sa'abah, Perilaku Seks Menyimpang dan Seksualitas Kontemporer Umat Islam, Yogyakarta : UII Pres , 2006.

Mieke Diah Anjar Yanit, dkk., Model Sistem Monitoring dan Pelaporan Anak dan Perempuan Korban Kekerasan, Propinsi Jateng : Bapenas 2006.

Johan Galtung, Kekuasaan dan Kekerasan, Yogyakarta : Kanisius, 1992.

Mieke Diah Anjar Yanit, dkk., Model Sistem Monitoring dan Pelaporan Anak dan Perempuan Korban Kekerasan, Propinsi Jateng : Bapenas 2006.

R. Soesilo, Kitab Undang-Undang Hukum Pidana Serta Komentarnya Pasal Demi Pasal, Bogor : Politea, 1991.

Soejono Sukanto, Kriminologi (Pengantar Sebab-sebab kejahatan), Bandung, Politea, 1987.

Topo Santoso, Kriminologi, Jakarta : Grafindo Persada, 2002.

Undang-undang Nomor 4 Tahun 1979 tentang Kesejahteraan Anak.

Undang-Undang Nomor 3 Tahun 1997 tentang Pengadilan Anak.

Undang-Undang Nomor 35 Tahun 2014 tentang Perlindungan Anak. 